\title{
Correlation between mental health and caries status in Primary School Students
}

\author{
Ayub I. Anwar*
}

CrossMark

\begin{abstract}
Objective: This study aims to determine the correlation of mental health and caries status of students in Mulia Bhakti Makassar Primary school.

Material and Methods: Analytical observational research with crosssectional study design. The subject of this research was all the students of Primary School Mulia Bhakti Makassar.
\end{abstract}

Results: The results showed a correlation between mental health and caries status with Pearson correlation test, $p=0.004(p<0.05)$ and correlation coefficient, $r=0.266$. There is a high index of DMF-T in students whose mental health is not normal.

Conclusion: There was a correlation between mental health status and dental caries status of students at Mulia Bhakti Makassar Primary School.
Department of Dental Public Health, Faculty of Dentistry, Hasanuddin University, Makassar, Indonesia
*Corresponding to: Ayub I. Anwar, Department of Dental Public Health, Faculty of Dentistry, Hasanuddin University, Makassar, Indonesia ayubanwar_mks@yahoo.com

Received: 5 November 2017 Revised: 17 January 2018 Accepted: 19 February 2018 Available online 1 August 2018

Keywords: Mental health, Caries status

Cite this Article: Anwar Al. 2018. Correlation between mental health and caries status in Primary School Students. Journal of Dentomaxillofacial Science 3(2): 108-111. D0l: 10.15562/jdmfs.v3i2.639

\section{Introduction}

Mental health is a person with a healthy mind and soul: feeling healthy and happy, able to face the challenges of life, accepting others as the way they are and being positive towards themself and others. Mental health can also be seen from various aspects: intellectual, social, spiritual-moral, emotional. ${ }^{1} \mathrm{~A}$ mentally healthy person has a normal personality. They will act and behave well to be accepted by the community. In addition, in their character, there is conformity with the norms and patterns of community life. ${ }^{2}$

School age is a time to lay a solid foundation for making a human have a certain quality and health is an important factor that determines the quality of human resources. School-aged children, especially primary school children, are a group that is prone to dental and oral diseases because they generally still have less self-supporting behaviours or habits for dental health. ${ }^{3}$

Dental and oral hygiene is very important. Some teeth and mouth problems can occur due to the lack of maintaining dental and oral hygiene, such as caries or holes in the teeth. Caries can affect anyone regardless of age.

All preventive measures, whether it is primary, secondary or tertiary prevention, should be based on clinical and radiographic examination, caries risk assessment, previous care outcomes, advances from prior caries history, parent and dentist's choice and expectations of care and reevaluation during periodic visits. ${ }^{4}$ Assessment of the individual caries risk level should be known by the dentist as all children are generally at risk of caries and treatment is also different at each level. The level of risk of childhood caries is divided into three categories: high, medium and low caries risk. The distribution of caries risk is based on previous caries experience, clinical findings, dietary habits, social history, fluorine use, plaque control, saliva and general medical history. ${ }^{4,5}$

Helpful information about maintaining and taking care of dental and oral health can be obtained by students easily from the counselling of community health clinic officers, teachers at school and existing media, such as television, posters and so on. ${ }^{6}$

The relationship between a life-threatening event and a mental disorder is very complex and depends on the person's individual situation and constitution. It really depends on the help of friends, and neighbours during periods of stress. Social structure, social change and social level achieved are very meaningful in one's life experience. A personality is a form of relative resilience in repetitive interpersonal situations typical for human life. The present behaviour is not an impulsive repetition of childhood history but is the retention of collection and retrieval.

Children are susceptible to caries and other oral diseases because they still need help from parents and family to guide them in maintaining their dental and mouth hygiene. Children with special needs also have a very high risk of dental hygiene and mouth problems because they have limitations in themselves. 
Dental caries is an infectious disease and is a progressive demineralization process on the hard surface tissue of the crown and tooth root that can be prevented. A caries risk is the possibility of caries development in the individual or the occurrence of changes in health status that support the occurrence of caries in a certain period. The risk of caries varies among individuals depending on the balance of precipitating and inhibiting factors of caries. The caries risk is divided into three levels: high, moderate and low caries risk. In order to identify the risk of child caries, a caries risk assessment was used. This assessment of caries risk is a clinical evaluation method in which the dentist can then adjust the prevention and care measures for each child. Assessment of caries risk should be performed on each child as a routine examination. ${ }^{8}$

The decayed-missing-filled teeth (DMF-T) index has been frequently used in epidemiological surveys of oral health. This index is recommended by the World Health Organization (WHO) to suppress and compare dental caries experiences in populations. This index shows a number of decayed teeth, missing teeth, and filled teeth in a group of individuals. ${ }^{9}$

In the 17 th century, the condition of a sick patient was only identified medically but by the 19 th century, medical experts realized that there was a connection between disease and human psychologic condition. This reciprocal relationship causes humans to suffer from physical disorders caused by mental disorders (somapsikotis) and otherwise mental disorders can cause physical (psychosomatic) illness. ${ }^{1}$

Professional prophylaxis (scaling, flour application) is performed by a dentist or child health worker. In children with physical and intellectual disabilities, this should be more emphasized. ${ }^{5}$

This study aims to determine the correlation between mental health and caries status in students at Mulia Bhakti Makassar Public School.

\section{Material and Methods}

This research is analytical observational research with cross-sectional study design. The subjects of this study were all students of Mulia Bhakti Makassar Primary School with age criteria $\geq 6$ years, present at the time of research, and willing to participate.

This study used the strengths and difficulties quistionnaire (SDQ). There were 25 questions that compared 5 scales and consisted of 5 statements on each scale. The answer choices consisted of "incorrect", "rather right" and "true". These five scales consisted of an emotional scale, a behavioural problem scale, a hyperactive scale, a scale of problems with peers and a prosocial scale. Scores for each answer option ranged from $0-2$, with a total score that can be obtained between 0-40. From the total score obtained, it can be interpreted to be: normal (0-15), moderate (16-19) and abnormal $(20-40) .^{10}$

Status of dental caries was assessed using the DMF-T index with criterion as very low $(0,0-1,1)$, low $(1,2-2,6)$, medium $(2,7-4,4)$, high (4.5-6.5) and very high $(>6.6) .{ }^{11-14}$

The data from the questionnaire and the caries status examination was processed using SPSS 23.0 for Windows and using Pearson correlation test to obtain the result of the research.

\section{Results}

Data was collected from 115 of 221 students at Mulia Bhakti Makassar Public School for both the SDQ and dental caries examinations.

Table 1 shows the distribution of the total sample by age and sex. There were 58 male students (50.4\%) and 57 female students (49.6\%). The most abundant males were 11 years age with 18 students (31.3\%) and the most abundant females were also 11 years of age with 14 students $(24.5 \%)$.

Table 2 shows the distribution of decay, missing, filling and average (DMF-T) values based on sex and mental health. This table shows the average DMF-T as a whole is in the moderate category $(3.71 \pm 2.20)$. The highest mean decay rate is in males $(3.41 \pm 2.29)$ and the highest mean filling rate is in females $(0.42 \pm 0.77)$ a very high DMF-T index in the abnormal mental health category $(9.50 \pm 0.70)$.

Table 3 shows the distribution of the sample based on mental health. The normal category contains 104 students (90.4\%), while moderate contains 9 students (7.8\%), and abnormal contains 2 students $(1.7 \%)$. This table shows the highest frequency of mental health is in the normal category.

Table 4 shows the correlation of mental health with DMF-T index. The normal mental health category of 104 students $(90.4 \%)$ have moderate caries criterion (3.41), while the moderate mental health.

\section{Table 1 Distribution of samples by age and sex}

\begin{tabular}{lcccccc}
\hline \multirow{2}{*}{ Age } & \multicolumn{2}{c}{ Male } & \multicolumn{2}{c}{ Female } & \multicolumn{2}{c}{ Total } \\
\cline { 2 - 7 } & $\mathbf{n}$ & $\%$ & $\mathbf{n}$ & $\%$ & $\mathbf{n}$ & $\%$ \\
\hline 6 & 8 & 13.7 & 5 & 8.8 & 13 & 11.3 \\
7 & 6 & 10.3 & 13 & 22.8 & 19 & 16.6 \\
8 & 9 & 15.5 & 7 & 12.3 & 16 & 14 \\
9 & 4 & 6.8 & 7 & 12.3 & 11 & 9.5 \\
10 & 13 & 22.4 & 11 & 19.3 & 24 & 20.8 \\
11 & 18 & 31.3 & 14 & 24.5 & 32 & 27.8 \\
Total & 58 & 100 & 57 & 100 & 115 & 100 \\
\hline
\end{tabular}


Table 2 Distribution of decay, missing, filling and average values (DMF-T) by sex and mental health

\begin{tabular}{|c|c|c|c|c|c|}
\hline \multirow{2}{*}{ Variable } & \multirow[b]{2}{*}{ n (\%) } & D & \multirow{2}{*}{$\begin{array}{c}\text { M } \\
\text { n (\%) (Mean } \pm \text { SD) }\end{array}$} & \multirow{2}{*}{$\begin{array}{c}\text { F } \\
\text { n (\%) (Mean } \pm \text { SD) }\end{array}$} & \multirow{2}{*}{$\begin{array}{c}\text { DMFT } \\
\text { n (\%) (Mean } \pm \text { SD) }\end{array}$} \\
\hline & & n (\%) (Mean \pm SD) & & & \\
\hline \multicolumn{6}{|l|}{ Sex } \\
\hline Male & $58(50.4)$ & $198(52.9)(3.41 \pm 2.29)$ & $7(38.8)(0.12 \pm 0.37)$ & $11(31.4)(0.19 \pm 0,47)$ & $216(50.6)(3.72 \pm 2.31)$ \\
\hline Female & $57(49.6)$ & $176(47.1)(3.09 \pm 2.02)$ & $11(61.1)(0.19 \pm 0.51)$ & $24(68.6)(0.42 \pm 0.77)$ & $211(49.4)(3.70 \pm 2.09)$ \\
\hline Total & $115(100)$ & $374(100)(3.25 \pm 2,16)$ & $18(100)(0.16 \pm 0.45)$ & $35(100)(0.30 \pm 0.65)$ & $427(100)(3.71 \pm 2.20)^{\star *}$ \\
\hline \multicolumn{6}{|l|}{ Mental Health } \\
\hline Normal & $104(90.4)$ & $311(83.2)(2.99 \pm 2.03)$ & $17(94.4)(0.16 \pm 0.46)$ & $27(77.1)(0.26 \pm 0.62)$ & $355(83.1)(3.41 \pm 2.01)$ \\
\hline Moderate & $9(7,8)$ & $47(12.6)(5.22 \pm 1.56)$ & $1(5.6)(0.11 \pm 0.33)$ & $5(14.3)(0.56 \pm 0.72)$ & $53(12.4)(5.89 \pm 1.36)$ \\
\hline Abnormal & $2(1,7)$ & $16(4.3)(8.00 \pm 0.00)$ & $0(0)(0.00 \pm 0.00)$ & $3(8.6)(1,5 \pm 0,70)$ & $19(4.4)(9.50 \pm 0.70)^{\star}$ \\
\hline Total & $115(100)$ & $374(100)(3.25 \pm 2.16)$ & $18(100)(0.16 \pm 0.45)$ & $35(100)(0.30 \pm 0.65)$ & $427(100)(3.71 \pm 2.20)^{\star \star}$ \\
\hline
\end{tabular}

${ }^{\star}$ A very high DMF-T index in the abnormal mental health category.

** The average DMF-T overall is in the moderate category.

Table 3 Distribution of samples based on mental health

\begin{tabular}{lcc}
\hline Mental Health & $\mathbf{n}$ & $\%$ \\
\hline Normal & 104 & 90.4 \\
Moderate & 9 & 7.8 \\
Abnormal & 2 & 1.7 \\
Total & 115 & 100
\end{tabular}

Table 4 Mental health correlations with DMF-T index

\begin{tabular}{lccc}
\hline Mental Health & $\mathbf{n}$ & DMF-T Mean \pm SD & Statistical Analysis \\
\hline Normal & 104 & $3.41 \pm 2.01$ & $\mathrm{r}=0.266^{*}$ \\
Moderate & 9 & $5.89 \pm 1.36$ & $\mathrm{P}=0.004^{* *}$ \\
Abnormal & 2 & $9.50 \pm 0.70$ & \\
Total & 115 & $3.71 \pm 2.20$ & \\
\hline
\end{tabular}

${ }^{*}$ coefficient correlation

${ }^{* *} \mathrm{P}<0.05$, significant
The most abundant age was 11 years old for both males and females with 18 students $(31.3 \%)$ and 14 students (24.5\%), respectively.

This is similar to studies conducted in Spain that indicates the prevalence of caries at 12 years of age reached $61.1 \%$ in males with a DMF-T of 1.52 . This is due to the consumption of sugary foods in this age group that increases while tooth brushing and dental visits are not of serious concern. ${ }^{15}$ In addition, Jabodetabek, shows that the mean DMF-T is high in the age group of 12 years old. The high average value of DMF-T can be due to the presence of hormonal fluctuations during puberty that results in salivary biochemical composition and reduced salivary flow rate causing the cavity to be more cariogenic in the 12-year age group. ${ }^{16}$

The caries status assessed by the DMF-T index showed that in general, the students had moderate caries status $(3.71 \pm 2.20)$. This study showed a correlation between mental health and caries status with the tendency of high DMF-T index in students with abnormal mental health. In this table, there was a significant correlation between mental health and caries status based off of $\mathrm{p}=0.004$ and correlation coefficient, $r=0.266$. This means that mental health only correlated with caries occurrence at $26 \%$ where there are $74 \%$ of other factors that influence caries status. In addition, the data analysis also shows the value of $p<0.05$ indicating a significant correlation between mental health and caries status.

These results suggest that the lower the mental health status of children with developmental disorders results in bad habits, such as nail biting or finger sucking, which can indirectly affect caries status on the childs teeth. ${ }^{10}$

Incorporating dental and oral health counselling in schools can be an alternative media for increasing knowledge and changing people's mindset about the importance of oral health. The percentage of caries 
status indicates that the government and related institutions should increase attention to dental and oral health in the form of preventive, curative, or promotive and rehabilitative action. This will affect the general health condition and affect the community activity or productivity in daily life.

\section{Conclusion}

Based on the result of the research, there is a correlation between mental health status and caries status in the students of Mulia Bhakti Makassar Primary School and the average DMF-T as a whole is in moderate category $(3.71 \pm 2.20)$.

\section{Acknowledgment}

Authors are also grateful to the Dean of Faculty of Dentistry Hasanuddin University for their support and assistance.

\section{Conflict of Interest}

The authors report no conflict of interest.

\section{References}

1. Setiawan Y. Definisi kesehatan mental. Jakarta: Word Press; 2017.

2. Giannopoulou L. Psychological treatments of trauma consequences in mental health. Ann Gen Hosp Psychiatry 2010;9: S30.

3. Pontonuwu J, Mariati NW, Wicaksono DA. Gambaran status karies anak sekolah dasar di Kelurahan Kinilow 1 Kecamatan Tomohon Utara. J e-Gigi 2013;1: 1-7.

4. Tinanoff N. Caries management in children: decisionmaking and therapies. Compend 2002;23: 9-13.
5. Malliori M. No health without mental health-towards a holistic approach. Ann Gen Hosp Psychiatry 2010;9: S35.

6. Suhaemi. Gangguan jiwa dalam perspektif kesehatan mental islam. J RISALAH 2015;26: 197-205.

7. Angela A. Pencegahan primer pada anak yang berisiko karies tinggi. Dent J 2005;38: 130-134.

8. Cyprianoa S, Maria da LR, de Sousab, et al. Evaluation of simplified DMFT indices in epidemiological surveys of dental caries. Rev Saude Public 2005;39.

9. Andersen R. Revisiting the behavioral model and access to medical care: Does it matter?. J Health \& Social Behavior 1995;36: 1-10.

10. Jorm AF. Mental health literacy. Public knowledge and beliefs about mental disorders. B J Psychiatry 2000;177: 396-401.

11. Lauber C, Nordt C, Falcato L, et al. Factors influencing social distance toward people with mental illness. Com Ment Health J 2004;40: 265-274.

12. Altweck L, Marshall TC, Ferenczi N, et al. Mental health literacy: a cross-cultural approach to knowledge and beliefs about depression, schizophrenia and generalized anxiety disorder. Front Psychol 2015;6: 1-12.

13. Veiga N, Pereira C, Amaral O. Prevalence and determinants of dental caries in a sample of schoolchildren of Satao, Portugal. Rev Port Estomatol Med Cir Maxilofac 2014;54: 215-216.

14. Smyth E, Caamano F. Factors related to dental health in 12 -year-old children: a cross-sectional study in pupils. Gac Sanit 2005;19: 113-119.

15. Akbar FH, Pratiwi R. Patient satisfaction againts the quality of dental health services at dental polyclinic of Tenriawaru general Hospital in Bone Regency. J Dentomaxillofac Sci 2016;1: 177-184

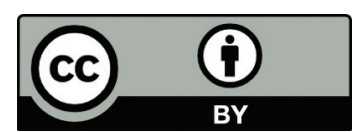

This work is licensed under a Creative Commons Attribution 